\title{
Germanika w zbiorach Biblioteki Uniwersyteckiej w Warszawie
}

P rzedstawione poniżej opracowanie na wstępie wymaga kilku niezbędnych wyjaśnień. Otóż powstało ono w 1993 r. jako materiał przeznaczony dla niemieckiego czytelnika, według ścisłych wytycznych co do konstrukcji pracy i zakresu informacji. Generalnie ma ono na uwadze obiekty drukowane od XV wieku po rok 1900, nie uwzględnia więc rękopisów. W niektórych przypadkach będzie jednak mowa o dziełach powstałych do 1918 r., a historia narastania zasobu obrazuje także fakty wynikłe z przebiegu II wojny światowej, bowiem miały one istotny wpływ na obecny stan germaników w bibliotekach polskich. Szkic ten znajdzie się $\mathrm{w}$ tomie omawiającym biblioteki polskie, przygotowanym w ramach serii prowadzonej przez prof. Bernharda Fabiana pt. Handbuch der historischen Buchbestände in Europa. Dotychczas ukazało się kilkanaście tomów obejmujących informacje o bibliotekach z poszczególnych regionów Niemiec w analogicznej serii Handbuch der historischen Buchbestände in Deutschland. Są one dostępne m.in. w czytelni bibliologicznej BUW pod sygnatura B.1591. Opracowywany obecnie tom „polski” powstaje dzięki współpracy Biblioteki Jagiellońskiej z Herzog August Bibliothek w Wolfenbüttel, choć redakcja centralna mieści się w Forschungsinstitut für Buchwissenschaft und Bibliographie uniwersytetu w Münster. Całość finansuje Fundacja Volkswagena.

Wedle niemieckich wydawców ma to być nowoczesny instrument pracy do badań bibliotekoznawczych, który orientuje w stanie dziedzictwa i stwarza zachęte do dalszej pracy bibliograficznej i naukowej nad historycznym zasobem bibliotecznym własnego narodu. Jest to zatem nieco inny sposób inwentaryzacji bibliotek (obok tradycyjnych katalogów i bibliografii), w którym istotna jest nie pojedyncza, choćby najwybitniejsza książka, czy inna forma druku, ale cały przechowywany zespół lub wybrana kolekcja.

$\mathrm{Z}$ tego powodu w przedstawionym opracowaniu musiały się znaleźć także informacje znane i oczywiste dla polskiego czytelnika. Zasób tych informacji był niestety limitowany obecnym stanem badań nad poszcze-

Z Badań Nad Polskimi Ksiegozbiorami Historvcznymi. 
gólnymi fragmentami zbiorów Biblioteki Uniwersyteckiej w Warszawie. Najdotkliwiej to widać $w$ odniesieniu do publikacji XIX wieku, które choć stanowią arcyciekawą część naszej spuścizny historycznej nie sá, ani dobrze zorganizowane jako kolekcja, ani nie są dobrze udokumentowane, ani nie znajdują odpowiednich badaczy. Tej luki, w tym stanie rzeczy, nie można było odpowiedzialnie wypełnić.

\section{Historia zasobu}

Biblioteka Uniwersytecka w Warszawie od początku swych dziejów miała być nie tylko warsztatem naukowym szkoły typu wyższego, ale też miała kontynuować ciagle żywe tradycje wywiezionej do Rosji po III rozbiorze Polski (1795 r.) Biblioteki Rzeczpospolitej Załuskich zwaną to znaczy miała być ogólnodostępną biblioteką publiczną z księgozbiorem dokumentującym dawne $\mathrm{i}$ bieżące piśmiennictwo polskie oraz europejskie tradycje kultury i nauki.

Powstała w 1817 r. biblioteka, od 24.III.1818 r. nazwana Biblioteka Publiczną przy Królewskim Uniwersytecie Warszawskim była od początku dobrze wyposażona $w$ dawne księgi, dzięki zabiegom jej pierwszego dyrektora Samuela Bogumiła Lindego (1771-1847), doświadczonego bibliotekarza i znakomitego znawcy tradycji książi i kultury. Biblioteka powstała na kanwie księgozbiorów szkół wyższych istniejących w Warszawie przed uruchomieniem uniwersytetu, tj. Szkoły Prawa i Administracji i Szkoły Lekarskiej. Dołączono też zbiory Liceum Warszawskiego oraz tzw. Biblioteki przy Sądzie Apelacyjnym. Organizowany od 1805 r. księgozbiór Liceum Warszawskiego, przechowywał zasoby XVIII-wiecznej Szkoły Rycerskiej oraz niektórych domów zakonnych. Znajdowała się tam ponadto wyborowa kolekcja książek europejskich XVI-XVIII wieku należąca ongiś do znanego biskupa-poety Ignacego Krasickiego (1735-1801), jak również duży zbiór Kazimierza Chromińskiego (1759-1816), prawnika i nauczyciela szkół w Lublinie, Wilnie i Świsłoczy oraz spora partia książek nabytych za granica, jak np. zespół pism reformacyjnych wrocławskiego bibliofila Johanna Efreima Scheibla (1736-1809), czy śląskiego orientalisty Samuela Weinischa (1700-1764). Zasobna w stare druki była także Biblioteka przy Sądzie Apelacyjnym gromadzona od 1810 r. przez Feliksa Lubieńskiego (1758-1848), ministra sprawiedliwości Księstwa Warszawskiego. Przewazały w niej ksiegozbiory klasztome, ale kupowano równiez świeckie kolekcje. Organizująca się 
książnica uniwersytecka, dzięki opiece ministra Wyznań Religijnych i Oświecenia Publicznego Stanisława Kostki Potockiego (1755-1821), mogła niebawem przyjąć wspaniałą kolekcję graficzną ostatniego króla Rzeczypospolitej Obojga Narodów Stanisława Augusta Poniatowskiego (1732-1798) oraz samego Potockiego, a także książki suspresjonowanych instytucji kościelnych, zwłaszcza męskich i żeńskich klasztorów oraz wiekowych kolegiat $\mathrm{z}$ terenu Królestwa Polskiego. Przejmowano również książki różnych szkół wojewódzkich, m.in. zasobną kolekcję z Kalisza. W 1820 r. włączono do zbiorów cenny księgozbiór pijarski z Łomży. Przejęto znaczny księgozbiór warszawskiej szkoły pijarów.

S.B. Linde rozwinął jednocześnie energicznie akcję zakupów starych druków i nowszej literatury do Biblioteki Publicznej w antykwariatach i na aukcjach zagranicznych w Paryżu, Wiedniu, Ratyzbonie, Lipsku, Kolonii, Frankfurcie nad Menem, Królewcu i Berlinie oraz w firmach włoskich. Rozwój Biblioteki Publicznej zahamowały represje po Powstaniu Listopadowym. 21 listopada 1831 r. został zamknięty Uniwersytet wraz z Biblioteką Publiczną a następnie większość zbiorów wywieziono do Petersburga, gdzie stały się integralną częścią Cesarskiej Biblioteki Publicznej oraz tamtejszej Akademii Nauk i innych książnic imperium rosyjskiego. Z 134067 jednostek tworzących bibliotekę warszawska wywieziono 90505 druków, 1856 rękopisów, 984 mapy oraz cały Gabinet Rycin. Część tych obiektów rewindykowano do Polski dopiero na mocy Traktatu Ryskiego z 1921 r. Do Biblioteki Uniwersyteckiej powrócił jedynie Gabinet Rycin, resztę przekazano do tworzącej się wówczas Biblioteki Narodowej, zbiory te w znacznej części spaliły się po upadku Powstania Warszawskiego w 1944 r. podpalone przez specjalne „Brandkommando”. Większość książek i czasopism pozostało w Rosji, ponieważ $b$. Cesarską Bibliotekę Publiczną uznano w postanowieniach traktatowych za pomnik dziedzictwa światowej kultury i zalecono wyłaczać z jej zbiorów tylko pozycje bezwzględnie konieczne.

Dawna Biblioteka Publiczna została w 1834 r. przemianowana na Bibliotekę Rządową, a w 1840 na Bibliotekę Warszawskiego Okręgu Naukowego. Przyłączono do niej pozostałą w Warszawie część Biblioteki Towarzystwa Przyjaciół Nauk z cennymi księgozbiorami po polskich uczonych m.in. fizyka i meteorologa Antoniego Magiera (1762-1837), filozofa i działacza politycznego ks. Stanisława Staszica (1755-1826) oraz pracującego iv Polsce proresora teologii i hebraisty Ludwila Alojzego Chiariniego (1789-1832). W 1834 i. począi wplywać znów egzemplarz 
obowiązkowy z terenu zaboru rosyjskiego. W 1838 r. Biblioteka Rządowa przyjęła zbiór książek po Adamie Maksymilianie Kitajewskim (1789-1837), znanym chemiku i technologu pierwszej połowy XIX w. Było $w$ nim sporo literatury zagranicznej z lat 1820-1830, zwłaszcza w języku niemieckim, $z$ zakresu matematyki, fizyki, geologii, mineralogii oraz nauk technicznych. W $1846 \mathrm{r}$. wpłynałł bardzo duży księgozbiór głównego cenzora Królestwa Polskiego - Józefa Kalasantego Szaniawskiego (1764-1843), czciciela i tłumacza dzieł Kanta, z piękną kolekcja dzieł słynnego filozofa oraz dotycząca ich rozbioru, a także idealistów niemieckich Fichtego, Schellinga, Hegla, Schleiermachera. W 1855 r. biblioteka wzbogaciła się o niewielką kolekcję książek ( $290 \mathrm{vol}$.) po swoim dyrektorze S.B. Lindem złożoną głównie z dzieł literatury klasycznej polskiej i niemieckiej. W latach 1840-1842 napłynęly z Petersburga „dary Najjaśniejszego Pana", czyli druki uznane za zbędne w zbiorach rosyjskich. Ich wartość dla nas była wszakże ogromna, bowiem pochodziły one z polskich księgozbiorów historycznych, głównie z Biblioteki Załuskich. Ogólnie można powiedzieć, że uzupełnianie zbiorów w tym czasie $w$ publikacje $\mathrm{z}$ zachodniej Europy było bardzo niewielkie, dominować zaczęly rossika, które z czasem stały się specjalizacją naszej biblioteki. Obecnie posiadamy największa tego rodzaju kolekcje w Europie (wydania do 1918 r.), naturalnie poza krajami b. ZSRR. Dawał się zauważyć ogromny brak czasopism naukowych, zwłaszcza przyrodniczych. Dopiero w 1852 r. odnotowujemy kontakt z firmą Schaaba w Moguncji. Począwszy od 1849 r. $\quad$ z Europy zachodniej napływało zaledwie od 2 do 142 dzieł rocznie. Prenumerowano m.in. poszyty reprodukcji galerii europejskich, m.in. drezdeńskiej i monachijskiej.

Ponowne aktywne gromadzenie książek, w tym zabytkowych, nastapiło w okresie odprężenia polityki Aleksandra Wielopolskiego (1803-1877), dyrektora Komisji Rządowej Wyznań Religijnych i Oświecenia Publicznego. W 1862 r. reaktywowano w Warszawie uniwersytet nazwany Szkołą Główną. Nazwę zmieniła również nasza książnica, nazwana odtąd Biblioteką Główną. Szkoła Główna i Biblioteka Główna zostały ponownie zamknięte $\mathrm{w} \mathrm{r} .1869$ jako kolejny akt represji na kulturze polskiej po upadku Powstania Styczniowego $1863 \mathrm{r}$. Ale zanim to sie stało - wznowiono energicznie zakupy zagraniczne. W latach 1861-1862 na licytacjach księgarskich w Lipsku oraz w księgarniach i antykwariatach Lipska, Kolonii i Frankfurtti nad Menem nabyto aż 3400 vol. książek. Zakupom tym patronowal profesor prawa Szkoły Głównej Romuald Hube 
(1803-1890). Kupiono wówczas 28 inkunabułów, 80 druków z XVI wieku, 162 z XVII oraz 411 z XVIII wieku. Przybyło także 9 średniowiecznych kodeksów pergaminowych, m.in. po Friedrichu Ludwigu Kellerze (1799-1860), profesorze historii prawa w Zurichu i Berlinie. Resztę stanowily druki z XIX wieku. Wśród nich przeważały publikacje prawne, źródła i opracowania historyczne, nauki pomocnicze historii, dzieła filologiczne, słowniki, katalogi bibliotek, bibliografie i podręczniki bibliotekarskie. Nabyto wówczas np. dzieła Martina Schrettingera (1772-1851), niemieckiego bibliotekarza i wydawcy znanego podręcznika Handbuch der Bibliothekswissenschaft (1834). Wśród zakupów przeważała zdecydowanie książka niemiecka, brak jednak było zupełnie wydawnictw $\mathrm{z}$ nauk przyrodniczych. Jednak po roku 1857 włączono do zbiorów Biblioteki Głównej książki medyczne ze zlikwidowanej warszawskiej Akademii Medyko-Chirurgicznej (4 000 vol.). Wzbogacono zespół druków prawnych, przejmując księgozbiór po rozwiązanej w 1861 r. Komisji Kodyfikacyjnej (3 000 dzieł w 5954 vol.) ze zbiorem praw niemieckich oraz Bibliotekę Komitetu Cenzury (3 302 dzieła w 6820 vol.), złożoną z książek i broszur zatrzymanych przed rozpowszechnianiem. W 1865 r. przejęto Bibliotekę Senacką (5 000 vol.), a trzy lata później Bibliotekę Rady Stanu (2 429 dzieł w 5752 vol.) z zakresu prawa, ekonomii, historiografii, wojskowości, wraz z czasopismami, m.in. uzyskano wtedy Allgemeine Preussische Zeitung $\mathrm{z}$ lat 1836-1844. Mimo wzmożonych wysiłków wokół uzupełniania zbiorów, w zasobie bibliotecznym tego okresu dają się zauważyć poważne luki w obrębie piśmiennictwa z I połowy XIX wieku, dotyczy to zwłaszcza czasopism. Pozyskiwano również księgozbiory prywatne, jak np. po zmarłym w 1856 r. Ignacym Turkulle (1798-1856), ministrze, sekretarzu stanu do spraw Królestwa Polskiego, absolwencie uniwersytetu wiedeńskiego (8 366 dzieł w 22192 vol.), ze znaczną ilością książek niemieckich z zakresu prawa, nauki o państwie, administracji, ekonomii, polityki, dyplomacji, wojskowości. W zbiorze tym uwagę zwraca zwłaszcza literatura niemiecka z okresu Wiosny Ludów, broszury odnoszące się do sprawy polskiej $z$ lat 1831-1855, ze spora grupa pism niemieckich, a także 257 tytułów czasopism, w tym dużo niemieckich o tematyce prawnej i ekonomicznej. Ciekawie prezentował się księgozbiór po profesorze matematyki Adrianie Krzyżanowskim (1788-1852). Coraz częściej nabywano księgi zabytkowe, m.in. od krakowskiego księgarza i historyka Ambrożego Grabowskiego (1782-1868) oraz wybitne przykła- 
dy sztuki typograficznej z kolekcji znanego bibliofila Kazimierza Stronczyńskiego (1809-1896).

W 1862 r. było opracowanych książek 59702 dzieł w 95642 vol., 2763 vol. czasopism, 92 atlasy, 118 luźnych map, 7842 poszytów rycin i nut, 4082 luźnych plansz rycin i nut, 577 rękopisów oraz 5887 numizmatów. Mając na uwadze również zbiory nieopracowane podaje się, że Biblioteka Główna liczyła ok. 200000 jednostek. Tak przynajmniej oceniał zasób, może z pewną przesadą jej bibliotekarz Karol Estreicher, największy polski bibliograf, twórca bibliografii narodowej. Warto zwrócić uwagę, że pośród nabytków po $1863 \mathrm{r}$. aż 1/3 dotyczyła bibliografii, historii ksiażki i drukarstwa, były to głównie nabytki $\mathrm{z}$ lat 1805-1863. Wówczas np. zaprenumerowano czasopismo Serapheum. Zeitschrift für Bibliothekwissenschaft, co wyraźnie wiązało się z planami Estreichera. Ponadto kupowano dzieła historyczne, z nauk pomocniczych, odnoszące się do historii ustroju, kultury, dzieła przyrodnicze i medyczne. Najwięcej publikacji przybyło w języku niemieckim, ponieważ był on dobrze znany profesurze warszawskiej, wśród której wielu było wychowankami uniwersytetów niemieckich. Charakterystyczne, iż nawet stynne dzieło Darwina trafiło do biblioteki w thumaczeniu niemieckim z 1860 r., a nie w o rok wcześniejszej edycji angielskiej. Po upadku Powstania Styczniowego w 1864 r. Bibliotekę Główną zalała nowa porcja zabytkowych zbiorów zakonnych, przede wszystkim z zamkniętych klasztorów warszawskich. Od 1865 r. następuje ruszczenie zasobów biblioteki.

Gdy Szkoła Główna została przekształcona w uniwersytet rosyjski, Biblioteka Główna w 1871 r. została mu podporządkowana jako Biblioteka Cesarskiego Uniwersytetu Warszawskiego. Nazwa ta obowiązywała do r. 1915, kiedy to w czasie I wojny światowej uniwersytet ewakuowano do Rostowa nad Donem, wywożąc przy okazji archiwum biblioteczne, kolekcję szczególnie cennych druków XV i XVI wieku (tzw. salę 28) oraz zgromadzony na nowo zasób rękopisów. Druki i rękopisy powróciły na mocy Traktatu Ryskiego z 1921 r. dopiero w r. 1925, archiwum biblioteczne przepadło. Zbiór starych druków wzbogacał się odtąd jedynie okazjonalnie, głównie dzięki darom osób prywatnych oraz niewielkim zakupom. Wspomnieć tu należy kolekcję starych druków pozyskana w 1874 r. z biblioteki prawnika Romualda Hubego (1803-1890) oraz profesora filologii klasycznej Ignacego Kossowicza. W 1879 r. otrzymano także filologiczny księgozbiór Hilarego i Leonida Łukaszewskich 
z Kazania, a w 1897 r. bibliofilską kolekcję Arkadija Tołoczanowa (1830-1897), prezesa Towarzystwa Kredytowego Ziemskiego. Przyjmowano też stare druki $z$ kasowanych lub reorganizowanych polskich ośrodków kulturalnych, jak np. płockie zbiory Szkoły Prowincjonalnej i Płockiego Towarzystwa Przyjaciół Nauk. Z końcem XIX wieku w r. 1899 otrzymano, wspaniała po dzien dzisiejszy, bibliotekę byłego Bankl Polskiego, bogatą w dzieła literackie, historyczne, teatralne, głównie dzięki zachowanej w niej kolekcji Kajetana Kwiatkowskiego (1700-1852), szambelana dworu ostatniego króla Polski - Stanisława Augusta Poniatowskiego. Przeważała w niej literatura francuska i polska, ale nie brak też oświeceniowych dzieł niemieckich. Wartościowy był także wielojęzyczny księgozbiór uzyskany po śmierci dyrektora Obserwatorium Astronomicznego Iwana Wostokowa (zm. 1898), członka niemieckiego Towarzystwa Astronomicznego, zamiłowanego podróżnika m.in. po Szwajcarii, Niemczech i terenach Austro-Węgier, skąd oprócz aktualnej literatury naukowej z dziedziny astronomii, matematyki, fizyki i geografii, przywoził dzieła literackie, m.in. po niemiecku oraz informatory, przewodniki i mapy.

$Z$ literatury nowszej kupowano przeważnie dzieła $z$ zakresu prawa, geografii, nauk ekonomicznych, matematyczno-przyrodniczych. W piśmiennictwie zachodnim wyraźnie preferowano język niemiecki, dobrze znany polskiemu i rosyjskiemu światu naukowemu, tak np. $90 \%$ piśmiennictwa z zakresu chemii wpływało w jęz. niemieckim. W $1901 \mathrm{r}$. wpływ książek $w$ jęz. polskim obejmował zaledwie 10\% nabytków (wykłady odbywały się $w$ jęz. rosyjskim), a piśmiennictwa niemieckiego sięgał $11 \%$, czyli lekko przewyższał literaturę narodową. W początkowych latach $\mathrm{XX}$ wieku specjalizowano się szczególnie $w$ dwóch dziedzinach, a mianowicie: piśmiennictwo starożytnego Rzymu i Grecji i stosownych do niego opracowań opublikowanych w Cesarstwie Rosyjskim oraz poza nim. Tak np. w latach 1905-1909 wpłynęły dzieła 28 pisarzy i myślicieli starożytnych wydane $w$ różnych krajach, w tym liczne niemieckie. Takiemu profilowi gromadzenia sprzyjał ówczesny kierownik biblioteki Siergiej Wiechow (1857-1919), z wykształcenia filolog klasyczny. $\mathrm{Na}$ Wydziale Historyczno-Filologicznym istniała oczywiście Katedra Literatury Greckiej i Rzymskiej, a także na tymże wydziale istniała Katedra Literatury Słowiańskiej, która przyczyniła się do wykrystalizowania się drugiej specjalizacji gromadzenia tego czasu. Zainteresowanie slawistyką było widoczne również i w Niemczech, czego wyrazem były odpo- 
wiednie katedry na uniwersytetach niemieckich (1841 - Berlin i Wrocław, 1870 - Lipsk). Stamtąd więc napływało wiele wydawnictw z zakresu slawistyki. Chętnie kupowano również publikacje bibliotekarskie z krajów niemieckojęzycznych. Tak np. w 1907 r. dla Oddziału Bibliograficznego biblioteki zakupiono 14 nowych czasopism i bibliografii, m.in. Bibliographisches Bülletin der Schweiz, Bibliographie der Deutschen-Zeitschritten-Literatur, Deutsches Journal-Catalog, BücherLexicon Kaisera i inne. Od 1895 r. literaturę zagraniczna nabywano za pośrednictwem księgarni warszawskiej Gebethnera i Wollfa, potem korzystano wprost z usług firm niemieckich, zwłaszcza tych, które udzielały korzystnego rabatu. W latach 1910-1913 kupowano m.in. w firmach lipskich F.A. Brockhaus, Gustav Fock, Alfred Lorenz, Karl V. Hiersemann, a także w firmie Karl Block, Breslau und Warschau, Mazowiecka 11. Wymieniano publikacje $z$ uniwersytetami niemieckimi, m.in. w Monachium.

Stan zbiorów za czasów rosyjskich, w 1871 r. przedstawiał się następująco: książek było 90084 dzieła w 161628 vol., czasopism 5008 vol., 164 atlasy, 1878 luźnych map, 130 rycin i 2709 poszytów z rycinami, 180 plansz nut i 2218 zeszytów z nutami, 742 rękopisy i 10412 jednostek numizmatów. Gdy Rosjanie ustępowali z Warszawy w 1915 r. opracowanych było 319956 dzieł w 608814 vol. oraz 1380 rękopisów różnej wartości. Sporo jednak książek w ogóle nie było wprowadzonych do inwentarza, nie licząc zbioru dubletów. W sumie był to wszakże księgozbiór niezbyt dobrze opracowany, w ogromnej mierze zrusyfikowany, na ogół trudno dostępny Polakom spoza uniwersytetu, $z$ nieporządkami w wypożyczaniu. Zawsze jednak należy pamiętać, że gdy Polska odzyskała niepodległość, ten właśnie księgozbiór, mimo rozmaitych mankamentów, nadal stanowił poważny warsztat pracy naukowej, zwłaszcza w zakresie historii i nauk pomocniczych, prawa, filologii i teologii.

W 1915 r. odrodził się polski Uniwersytet Warszawski. Biblioteka weszła $w$ jego skład jako jeden z zakładów $\mathrm{i}$ otrzymała wówczas nazwę obowiązującą do dziś - Biblioteka Uniwersytecka w Warszawie, zwana popularnie BUWem. Okres międzywojnia to czas gwałtownej polonizacji zbiorów oraz akcja ich unowocześniania. Czytelnictwo piśmiennictwa obcego odbywało się głównie poprzez język francuski i niemiecki. Tak np. w roku akademickim 1932/33 zrealizowano z magazynu 4718 zamówien na ksiązki fancuskie 1283 ná nienieckie, I 484 na rosyjskie 
i tylko 968 na angielskie. W następnym roku akademickim zrealizowano 4348 zamówień na piśmiennictwo francuskie i 3512 na niemieckie, wydano też 1586 książek w jęz. rosyjskim i $1068 \mathrm{w}$ angielskim. Podobne proporcje były w sezonie 1934/35 - francuskich książek udostępniono 4 420, niemieckich 4 256, rosyjskich 1694 i angielskich 1144.

Przed wybuchem II wojny światowej w 1939 r. Biblioteka Uniwersytecka w Warszawie była największą instytucją biblioteczną w kraju. Stan jej zbiorów wyglądał w tym czasie następująco: druków 820 000, rękopisów 4 132, rysunków i rycin 103 604. Poważniejsze straty poniosła nasza biblioteka podczas wojny w odniesieniu do historycznych zbiorow, które stały się częścią nowej jednostki organizacyjnej „Sondersammlungen Abteilung III”, utworzonej przez Niemców „Staatsbibliothek Warschau”. Zostały one przewiezione do budynku Biblioteki Ordynacji Krasińskich przy ul. Okólnik. Tam spłonęło w 1944 r. m.in. około 300 inkunabułów. Stare druki wywożono też do Pruszkowa i dalej na teren Austrii, Niemiec, Śląska, skąd po wojnie szczęśliwie powróciły, choć w stanie zawilgocenia, brudu i znacznego zniszczenia. Odnosi się to zwłaszcza do kolekcji druków XVI wieku, wspomnianej już wcześniej tzw. 28 sali, którą w 1915 roku wywieźli Rosjanie, a w 1944 r. Niemcy. Dziś cały ten zespół wymaga szczegółowej interwencji konserwatorskiej, na którą wciąż nie ma odpowiednich środków. Największych jednak strat doznał zasób rękopisów, spalony w 95\% swego przedwojennego stanu oraz Gabinet Rycin, którego obiekty uległy zniszczeniu od $45 \%$ do $62 \% \mathrm{w}$ poszczególnych zespołach.

Po 1945 r. Biblioteka Uniwersytecka przejęła nieco książek z tzw. księgozbiorów zabezpieczonych, przeważnie poniemieckich, głównie $z$ terenu Pomorza. Odbierano transporty ze stacji kolejowej w Sobowidzu k. Gdańska (Sobbowitz - ok. 2000 vol.), ze stacji Pszczółki w woj. gdańskim (Hohenstein - 39 skrzyń), z magazynu kolejowego w Szczecinie (Stettin - 43 skrzynie), ze Słupska (Stolp) i Koszalina (Koslin). Znacznie mniej książek przywędrowało z Dolnego Śląska. W porównaniu z innymi bibliotekami naukowymi w Polsce kolekcji poniemieckich nie jest w BUW zbyt wiele, a to dlatego, iż zdołaliśmy ocalić w zdecydowanej większości swój przedwojenny zasób. Nie było więc ani potrzeby, ani miejsca na przyjęcie nowych kolekcji. Tym niemniej jednak warto zasygnalizować kilka grup proweniencyjnych, zapewne interesujących dla niemieckich i polskich historyków kultury 
Cennym zespołem jest księgozbiór obfitujący w stare druki, należący do ordynackiej biblioteki rodu Schönaichów z Siedliska i Bytomia Odrzańskiego (Carolath-Beuthen), przejęty na przełomie marca i kwietnia $1946 \mathrm{r}$. w postaci ,jednego wagonu książek", jak zapisano w dokumentach. Rodzina ta pozostawała przez wiele stuleci w ożywionych kontaktach z Polakami, a niektórzy z nich używali spolszczonej formy nazwiska „Krasnodębski”. Twórcą książnicy był Georg Schönaich (1557-1619), fundator słynnego gimnazjum w Bytomiu Odrzańskim, gdzie edukowała się także i polska młodzież. Swoje księgi książę Jerzy podpisywał własnoręcznie, często zaznaczając miejsce nabycia, a nawet cenę. Kolekcja wyróżniała się charakterystyczną oprawą w białą świńską skórę ze ślepymi tłoczeniami, z odbitym na wierzchniej okładzinie superekslibrisem w postaci plakietki herbowej ze słabo widocznymi literkami GvS (=Georg von Schönaich). Obecnie w kartotece proweniencyjnej są zarejestrowane tylko druki z XVI wieku, których jest ponad dwieście. Zasób XVII-XIX wieku jest wprowadzony do inwentarzy i katalogu alfabetycznego, ale nie ma opracowania proweniencyjnego. Na książkach późniejszych często spotyka się podpis Henryka Karola Wilhelma Schoenaicha, od 1854 r. członka Izby Panów. Księgozbiór Schönaichów opatrzono także pieczątką własnościową: „Majorats-Bibliothek zu Carolath”. Stanowią go głównie pozycje historyczne, teologiczne, prawnicze, klasyka grecka i rzymska, silesiaca.

Na uwagę zasługuje też fragment Heskiej Biblioteki Wielkoksiążęcej książat Hessen-Darmstadt, zwykle opatrzonej pieczątkami „HSB” lub "Grossherzogliche Kabinettsbibliothek". Zespół ten wpłynął do naszych zbiorów za pośrednictwem Muzeum Narodowego w Warszawie w lutym 1946 r. w postaci ok. 90 skrzyń, tj. ok. 4000 druków XVI-XIX wieku. Jest to fragment wspaniałej biblioteki dworskiej, bogaty w dzieła literackie ( $m$.in. dzieła Opitza), teatralia, libretta oper, poezję panegiryczną i okolicznościowa, rozporządzenia. Książki opatrzone są ładnymi oprawami, jeśli idzie o druki XIX wieku, wcześniejsze często są oprawione w pergamin. Obecnie w kartotece znaków własnościowych znajduje się ok. 50 dzieł z XVI wieku tej proweniencji, reszta jest ujęta tylko w katalogu alfabetycznym.

W grudniu 1949 r. gmina ewangelicko-reformowana z Kamiennej Góry (Landeshut) na Dolnym Śląsku przekazała nam księgozbiór miejscowej biblioteki (Wallenstein-Fencieglinsche Bibliother). Liczy on kilkanaście tysięcy książek, w tym ok. 6500 starych druków. Fundatorem 
tej ksiażnicy był Melchior Ducius von Wallenberg zm. 1727, a późniejszym znacznym ofiarodawca Lucas Fenderlich zm. 1794 oraz jego żona Anna Rosina zm. 1829. Zbiór ten obejmuje w zasadzie wszystkie dziedziny wiedzy, z piękną reprezentacją tematyki śląskiej i problemów kościoła protestanckiego. Ma on dwa drukowane katalogi: Wilhelma Perschkego z 1829 r. oraz Theodora Langnera z 1881 r., jest więc nieźle rozpoznany. Jednak w 1968 r. doszło w BUW do mocno kontrowersyjnej decyzji przekazania wydzielonych starych druków (6 404 vol.) do Biblioteki Uniwersyteckiej $w$ Łodzi. U nas pozostawiono wszakże 7 inkunabułów oraz kilka szczególnie cennych druków z XVI wieku (m.in. Sachsenspiegel, Leipzig 1595), a także zasób XIX-wieczny, którego część zdubletowano. Dubletowano i wymieniano niestety i inne zespoły dziewiętnastowieczne bibliotek poniemieckich, nie zważając na całości proweniencyjne.

Kilkaset książek ujętych w kartotekach proweniencyjnych reprezentuje księgozbiór ks. Ernesta Blecha (1846-1922), historyka Gdańska i proboszcza kościoła św. Katarzyny w tym mieście. Odnoszą się one głównie do historii Pomorza i Gdańska, a pochodzą głównie z XIX i początków XX wieku, choć odnotowano takze jeden inkunabuł tej proweniencji. Książki są oznaczone odręcznym podpisem właściciela, datą nabycia, a często znajdujemy także informację o cenie.

Bardzo wyrywkowo są reprezentowane inne księgozbiory ślaskie i pomorskie. Spotykamy np. pojedyncze obiekty oznaczone superekslibrisem literowym GRHZLUB, co należy rozwiązać następująco: Georg Rudolph Herzog zur Legnitz und Brieg (1595-1653). Wśród ksiązek XIX wieku odnajdujemy oznakowane pieczątka „Graf Yorck Klein-Oels Majorats-Bibliothek" należącą do zbioru książęcego z Oleśniczki. Wśród starych druków można wyodrębnić grupę publikacji z biblioteki gimnazjum szczecińskiego, oznaczonych odręcznym zapisem lub pieczątką „Ex Biblioth. Gymn. Pal. Sedinensis". Dotychczas w kartotece proweniencyjnej starych druków ujęto 80 egzemplarzy tej proweniencji. Odnajdujemy też nieliczne druki z książnicy koszalińskiej (Biblioteca Schwederiana). Od czasu do czasu trafiamy na powojenne nabytki z biblioteki berlińskiej (Biblioteca Regia Berolinensis, Koenigliche Bibliothek Berlin), które korespondują z innymi książkami tej proweniencji, pochodzącymi z zakupów na XIX-wiecznych aukcjach.

Zupełnie odmienne miejsce zajmuje historyczna kolekcja, która choć ściśle związana z kulturą niemiecka bula uksztaltowana przez Polaków iw Polsce Chodzi tu o ksiegozbió pochodzacy z Warszawy, a mianowi- 
cie Synodu Ewangelicko-Reformowanego oraz Zboru Warszawskiego, przechowywany do końca wojny przy ul. Leszno. W lutym 1945 r. superintendent tegoż kościoła ks. Stefan Skierski przekazał go w formie wieczystego depozytu do Biblioteki Uniwersyteckiej w Warszawie. Zawierał łącznie 7286 książek (z tego 2145 dzieł w 2759 vol. starych druków), ponadto 931 rękopisów oraz 51 pieczęci. Ten księgozbiór jest w opłakanym stanie fizycznym, bowiem stare księgi i bezcenne rękopisy przeleżały jesień i zimę 1944/45 roku w zrujnowanych pomieszczeniach bez szyb okiennych. Stare druki z tego zespołu mają osobną kartotekę proweniencyjna która ujawnia pasję zbieracką książek wśród wielu polskich rodzin protestanckich. Spotykamy w niej nazwiska szlacheckie Bielskich, Karczewskich, Koszkielów, Kołyszów, Kurnatowskich, Nieszkowskich, Russockich, Stryjeńskich, Suchodolskich, Świdów, Twardowskich, Wolanów. Rozpoznajemy też nazwiska rodzin mieszczańskich warszawskich dysydentów: Braunigów, Jacobsonów, Kaechtlerów, Michlerów, RaageRagowskich, Schultzów. Ze wzruszeniem bierzemy do rąk książki należące ongiś do warszawskich duchownych protestanckich, jak np. luteranina pastora Karola Schmidta, pastora wyznania reformowanego Karola Bogumiła Diehla (z ekslibrisem portretowym), czy Samuela Adama Hartmanna. W księgozbiorze tym najliczniej jest reprezentowana polska i europejska literatura reformacyjna, w tym zwłaszcza $z$ niemieckiego obszaru językowego. Nas szczególnie zajmuje obecność sporej liczby rzadkich polskich germaników, jak np. kazania, kancjonały, modlitwy, katechizmy drukowane w Polsce na potrzeby gminy warszawskiej.

Biblioteka nasza jest obecnie trzecią co do wielkości biblioteką uniwersytecką w Polsce. Jej zbiory są gromadzone zgodnie z potrzebami naukowymi i dydaktycznymi Uniwersytetu. Ponadto Biblioteka Uniwersytecka w ogólnokrajowej sieci bibliotek pełni od kilku lat funkcje I Centralnej Biblioteki Nauk Społecznych z następującym zakresem specjalizacji zbiorów: filozofia, historia, nauki polityczne, polityka, nauki prawne, państwo i prawo, administracja państwowa ( $\mathrm{z}$ wyłączeniem ustawodawstwa $\mathrm{i}$ orzecznictwa oraz literatury $z$ tym związanej), naukoznawstwo, prognozologia, pedagogika, oświata, szkolnictwo, psychologia, socjologia. 


\section{Opisy zasobów}

\section{Przegląd chronologiczny}

Stan zbiorów Biblioteki Uniwersyteckiej w 1991 r. obejmował 2208519 jednostek, w tym druków zwartych 1411 656, czasopism 567 236, zbiorów specjalnych 241 450. Ponadto w bibliotekach zakładowych Uniwersytetu Warszawskiego tworzących z Biblioteką Główną wspólną sieć biblioteczną znajduje się 1899048 jednostek, w tym druków zwartych 1383874 , czasopism 314078 i zbiorów specjalnych 201096 jednostek. Jednakże zbiory specjalne bibliotek zakładowych nie dorównują rangą zbiorom zgromadzonym w gmachu głównym biblioteki.

Biblioteka posiada ok. 130000 starych druków, czyli publikacji wydanych przed $1801 \mathrm{r}$. Zespół ten jest wydzielony magazynowo i katalogowo. Znajduja się w nim 142 inkunabuły i ok. 12000 druków XVI wieku. W zdecydowanej większości są to druki obce, polonica stanowią ok. $25 \%$ całości zasobu. W podziale na języki obce prymat dzierży łacina, następnie francuski, niemiecki, włoski, angielski, rosyjski i inne pomniejsze. Najbardziej precyzyjne dane można podać w stosunku do piśmiennictwa XV i XVI wieku.

Zbiór inkunabułów liczy 142 dzieła, z czego 85 należy do niemieckiego obszaru językowego. Najwięcej druków piętnastowiecznych pochodzi z Norymbergi (19), Strassburga (18), Lipska (15), Bazylei, Kolonii i Spiry (po 6). Są to przeważnie księgi w języku łacińskim, jedynie 6 dzieł toczono po niemiecku.

Wśród publikacji z XVI w. na niemiecki obszar językowy przypada ok. 50-60\% całego zasobu druków z tego okresu, czyli do 6000 vol. Najliczniej sa reprezentowane oficyny Bazylei oraz Kolonii. Znaczna część renesansowych druków pochodzi z Frankfurtu nad Menem, z Lipska, Wittenbergi i Strassburga. Należy wyraźnie podkreślić, że w naszej kolekcji druków XVI w. w grupie piśmiennictwa pochodzącego z obszarów niemieckojęzycznych, zdecydowanie dominuje język łaciński, który obejmuje prawie $80 \%$ pozycji. Reszta przypada na język niemiecki (także dolnoniemiecki), grecki, hebrajski oraz w kilku przypadkach słowieński (wendecki).

W zakresie druków XVII-XVIII wieku możemy jedynie podać wielkości szacunkowe, ale i w tej grupio nie dominuje języ niemiecki. Biorąc 
pod uwage produkcję drukarską Austrii, Niemiec i Szwajcarii z tego okresu zachowaną $w$ naszym zbiorze, można przyjąc, iż stanowi ona ok. 40\% zasobów obcojęzycznych, czyli ok. 47000 druków, licząc całą wydajność pras, tj. łącznie z książkami łacińskimi. Natomiast publikacje w języku niemieckim szacujemy na ok. 20\% zawartości zbiorów obcojęzycznych XVII-XVIII wieku.

Wielkość zbiorów obcojęzycznych XIX w. w stosunku do całości zasobu jest, przy obecnym stanie badań nad historią biblioteki, niemożliwa do określenia. Nie są one wydzielone, ani magazynowo, ani katalogowo. Jednakże można powiedzieć $\mathrm{z}$ dużą dozą prawdopodobieństwa, że wśród piśmiennictwa obcego tego okresu przeważają rossika, następnie publikacje francuskie (nauki humanistycze), potem dopiero niemieckie (głównie nauki matematyczno-przyrodnicze, slawistyka i filologia klasyczna), w mniejszym stopniu angielskie.

\section{Przegląd systematyczny}

Brak katalogów rzeczowych oraz wydzielonych inwentarzy uniemożliwia podanie w pełni precyzyjnej charakterystyki kolekcji starych druków. Omówimy zatem szerzej jedynie piśmiennictwo najstarsze, o którym można informować odpowiedzialnie w wyniku przeprowadzonej akcji formatowania, przekatalogowania i przesygnowania książki XVXVI w. $z$ naszych zasobów.

\section{Inkunabuły i druki XVI wieku}

Pośród inkunabułów, czyli druków z XV wieku, posiadamy 3 pozycje tłoczone w języku niemieckim, odnotowane jako jedyne egzemplarze zachowane w Polsce. Sa to druki: Ioannes de Paltz Die Himmlische Fundgrube (Leipzig, M. Landsberg, nie przed 1490); Otto von Passau Die vierundzwanzig Alten (Koln, 26 V 1492); Gart der Gesundheit (Augsburg, 13 VIII 1493). Znane dzieło B. Breidenbacha Die heyligen Reyssen gen Iherusalem (Mainz, E. Reuwich, [typ. P. Schoffen], 21 VI 1486) należy do jednego $z$ dwóch egzemplarzy przechowywanych w Polsce, a druk Reformation der Stadt Nürnberg (Nürnberg 5 VI 1484) do jednego $\mathrm{z}$ trzech. Wszystkie wymienione pozycje są interesująco ilustrowane. Tematycznie wśród inkunabulistycznych germaników przeważa teologia i filozofia w ujęciu średniowiecznej scholastyki 
oraz komentarze do prawa kanonicznego i rzymskiego (13). Znajdujemy także księgi liturgiczne (4), komentarze do Biblii (6), edycje dzieł Ojców Kościoła (3), dzieła klasyków starożytności (2) oraz druki użytkowe (kalendarze, kroniki, zielniki, opisy podróży, żywoty świętych razem 10$)$.

W zespole germaników XVI wieku najwięcej pozycji zaliczyć można do działu teologicznego (ok. 1500 vol.). Stanowią go komentarze do Biblii (ok. 400), zarówno autorów katolickich jak i protestanckich, wydania Biblii w całości oraz poszczególnych jej ksiag (ok. 140, w tym 28 w jęz. niemieckim, 20 po grecku i hebrajsku), edycje dzieł Ojców Kościoła (ok. 100, głównie edycje bazylejskie), historii Kościoła wraz z uchwałami soborów w Kolonii i Trydencie, zbiory kazań i poszczególne homilie, jak np. Johanna Wilda zwanego Ferusem (ok. 30), Martina Eisengreina (14), dzieła pisarzy i działaczy katolickich, zwłaszcza jezuitów, wydawane w Kolonii i Ingolstadzie (m.in. Canisius, Osorius, Ribadeneira, Suarez, Toletus), katechizmy i indeksy ksiag zakazanych (ok. 20), księgi liturgiczne, w tym kilkanaście druków muzycznych, żywoty świętych, jak np. św. Gertrudy, Jadwigi, Ulryka.

Dużą grupę tematyczną stanowią druki związane z ruchem reformacyjnym, w tym ok. 200 wydań Lutra lub do niego się odnoszące. Wśród zwolenników Lutra wymienić można edycje pism Melanchthona (ok. 190), Johanna Brenza (35), Martina Bucera (23), Mathiasa Flaciusa (ok. 40), Christopha Pezeliusa (11) i Johanna Spangenberga (14). Mamy także prace przeciwników Lutra, a mianowicie Johanna Cochlaeusa (36 wydań), Johanna Ecka (25), czy Johanna Hofmeistra (26). Są też pisma przedstawicieli innych grup reformacyjnych, jak np. Sebastiana Francka, Kaspara Schwenckfelda, Johanna Oecolampadiusa (ok. 30), Erazma z Rotterdamu (152) i erazmiańczyków, jak np. Johann Gropper (18), Michael Helding (11), Georg Witzel (35). Ważnym zjawiskiem jest literatura polemiczna wokół znanych wydarzeń oraz spornych problemów teologicznych. Tak np. do Konfesji Augsburskiej odnosi się ponad 30 wydań, sporo różnych druków nawiązuje do tzw. Interimu (z Ratyzbony, Augsburga, Lipska), do Concordii (Konkordienbuch, Formula Concordiae, tzw. Bergische Buch).

Około 400 woluminów to wydania greckich i rzymskich pisarzy klasycznych. Pochodzą one głównie z oficyn Bazylei, Lipska, Frankfurtu, Heidelbergu. Największą ilością wydan jest reprezentowana twórczość Cicerona (ok. 75, w tym także tłumaczenia niemieckie) 
Mniej niż 300 tomów stanowi dział prawa, który obejmuje przede wszystkim komentarze do prawa rzymskiego w całości lub do poszczególnych jego zagadnień, takich autorów jak, m.in. Johann Borcholten, Johann Oldendorp, Andreas Perneder, Johann Schneidewin, czy Mattheus Wesenbeck. Niewiele pozycji reprezentuje prawo magdeburskie (Sachsenspiegel - Leipzig 1539, 1569, 1589, 1595, Dresden 1553, Frankfurt am Mayn 1600), ówczesne prawo karne (np. Die PeindlichHals-Ordnung Karola V (Mainz 1533, 1545, Frankfurt am Mayn 1563, 1575)), prawo ogólnoniemieckie oraz poszczególnych księstw, jak np. Styrii, czy miast - Bambergu, Miśni, Norymbergi i innych.

Dział historii i geografii obejmujący ok. 200 woluminów gromadzi dzieła $\mathrm{z}$ zakresu historii ogólnej i geografii Europy oraz całego znanego ówcześnie świata. Są to nieraz księgi wspaniale ilustrowane, by wspomnieć atlasy Georga Brauna (Civitates orbium terrarum Köln, 1573-1617) czy Sebastiana Münstera (Cosmographiate universalis libri IT Basel 1550, 1554, 1559, 1572 i 1598) lub też dzieła wydane w oficynie firmy de Bry. Spotykamy opisy poszczególnych regionów (Brandenburgii, Saksonii), państw - jak choćby Francji i Hiszpanii, miast - Augsburga, Greifswaldu, Oldenburga. Często wykorzystywane przez czytelników są kroniki zdarzeń historycznych, by wymienić znanych autorów: Johanna Cariona, Laurentiusa Suriusa czy Johanna Sleidana. W dziale tym można znaleźć interesującą korespondencję jezuickich misjonarzy z wizytowanych terenów: $\mathrm{z}$ Chin, Japonii, Ameryki. Wyodrębniają się też tzw. turcica, czyli druki nawiązujące do zagrożenia Europy przez inwazje turecka. W tej dziedzinie celują pisma Johanna Leunclaviusa (Lowenklau). Do działu biografii i genealogii zaliczyć można ok. 20 wydań, wśród których odróżniamy opracowania o poszczególnych rodach, panegiryki związane zarówno z życiem panujących książąt, jak i znanych osób z różnych sfer oraz dzieła ogólne z zakresu heraldyki (Wappenbuch, Stammbuch).

Porównywalny pod względem ilości woluminów jest dział nauk przyrodniczych. Stanowią go dzieła medyczne zarówno autorów starożytnych jak np. Galena (14 edycji) czy Hippocratesa, jak też autorów szesnastowiecznych, choćby Paracelsusa (15 wydań), Leonharda Fuchsa, Johannesa Andernacusa Guinteriusa, Andreasa Vesaliusa, Christopha Wirsunga. Liczne są dzieła $z$ zakresu aptekarstwa, w tym szczególnie farmakopee oraz zielniki (Kreuterbuch, Merbarium). Okolo 90 wydan przypada na astronomię. Zaliczamy tu min. prace Georga Purbacha, Polenieusza, 
Johanna Regiomontana, Valentina Naboda, Messahalaha [Ma Sha Allah, al Misri] oraz oczywiście Mikołaja Kopernika. Kilkanaście druków reprezentuje matematykę i geometrię.

Językoznawstwo, gramatyka, ortografia - to kolejny dział liczący ok. 100 woluminów. Oprócz rozpraw teoretycznych związanych z językiem greckim, łacińskim, hebrajskim takich autorów, jak: Nicolaus Clenardus, Joachim Camerarius, Elia Levita, Thomas Linacre, Petrus Mosselanus, Sebastian Münster czy Johan Reuchlin, mamy słowniki (22 wydania bazylejskie Lexiconu Calepina) oraz kilka gramatyk niemieckich, m.in. Fabiana Franckego Gemma gemmarum z 1501 r. i dolnoniemieckich, jak np. Alberta Oelingera Underricht der Hoch Teutschen Sprach: Grammatica seu institutio verae Germanicae linquae (Strassburg 1574) dedykowana Polakowi Konradowi Przecławskiemu, sekretarzowi królewskiemu.

Niewielki jest dział literatury (ok. 50 pozycji), ale spotykamy tu dzieła reprezentujące typowe kierunki dawnej literatury niemieckiej, by wskazać np. satyrę (utwory Sebastiana Branta, Johanna Geilera von Kayserberg, Johanna Fischarta, Philipsa van Marnix), bajkę i powiastkę ludową (historie o Meluzynie, Lotharze, zburzeniu Troi), romans rycerski (np. pierwsze wydanie Theuerdancku z 1517 r., jeden z dwóch egzemplarzy przechowywanych w Polsce), zbiory przysłów (pierwsze wydanie Sprichtwörtter Joannesa Islebiusa Agricoli z 1529 r.), edycję znanych Fastnachtspiele Bernharda Herxheimera (Leipzig 1560). Mamy także niektóre zbiory poezji, m.in. Balthasara Exnera i Michaela Hasloba.

\section{Druki XVII i XVIII wieku}

Wśród druków późniejszych pochodzących z XVII i XVIII wieku największą grupę stanowi piśmiennictwo teologiczne (pozostałość po nieistniejącym już na uniwersytecie wydziale teologicznym oraz spuścizna licznych bibliotek klasztornych i kolegiackich) z dużą ilością książek odnoszących się do protestantyzmu, a także związanych z rozmaitymi kontrowersjami religijnymi. Warto zasygnalizować interesujący zbiór protestanckich śpiewników religijnych (kancjonałów), opracowanych głównie na użytek kościoła luterańskiego (ok. 150 edycji) i kalwińskiego (ok. 30). Kilka wydań przynależy do zboru braci czeskich oraz sekty mennonitów (np. Marienwerder-Kwidzyń 1780). Kancjonały są zgroma- 
dzone w katalogu pod hasłem „Gesangbuch" i ułożone według regionów, których dotyczą.

Znacząca grupa publikacji w obrębie germaników XVII-XVIII wieku jest piśmiennictwo prawne, zwłaszcza komentarze do Kodeksu Justyniana oraz dysertacje akademickie $z$ różnych uczelni o tematyce prawniczej.

Liczną i atrakcyjną częścią zbioru jest zasób literatury niemieckiej i to zarówno barokowej (np. 15 edycji utworów Martina Opitza), jak i pisarzy niemieckiego Oświecenia, których rozmaitych wydań nie sposób wymienić. Zwracamy uwag̨ także na piśmiennictwo filozoficzne szczególnie obficie jest reprezentowany dorobek Kanta, nie licząc wydań zbiorowych mamy ok. 45 edycji jego utworów drukowanych przed rokiem 1801.

Wśród germaników zaznaczają się ciekawe polonika treściowe, jak np. cały zespół niemieckich utworów związanych z osobą walecznego króla Polski Jana III Sobieskiego i jego udziałem w bitwie wiedeńskiej 1683 r., by wspomnieć choćby druczek autorstwa Christiana Wilhelma Huhna Nichts Neues und nicht Altes oder umbstandliche Beschreibung was Anno 1683 von bey und in der... Tuerckischen Belagerung Wien vom 7 Julii biss 12 September... taglich vorgelauffen (Bresslau 1717), czy Relatio historico-politica... (Sultzbach 1684). Germanikami nazwiemy też niemieckie wydania polskich pisarzy i uczonych, tłoczone po łacinie $\mathrm{i}$ w języku niemieckim na niemieckim obszarze językowym, jak i po niemiecku na terenie Rzeczypospolitej Obojga Narodów. Dla ilustracji przypomnijmy utwory Andrzeja Maksymiliana Fredry, jak np. Monita politico-moralia wydane we Frankfurcie nad Menem w 1719 r. oraz w Wiedniu w 1748 roku. Wersja niemiecka tegoż utworu zatytułowana Staats und Sitten Lehren ukazała się we Frankfurcie w 1698 roku. Inne dzieło Fredry Scriptorum seu togae et belli notatiomum selecta drukowano w tymże mieście w 1685 roku. W zbiorach BUW przechowujemy także niemieckie tłumaczenia utworów czołowych pisarzy polskiego Oświecenia, jak choćby Ignacego Krasickiego Begebenheiten des Nic. Doświadczyniski (Warschau 1776), Herr Untertruchses (Warschau 1779) i Maeuseade (Warschau-Leipzig 1790), czy Juliana Ursyna Niemcewicza Die Ruckkehr des Reichstagsgesandten (WarschauLeipzig 1792). Szeroko znana była w Niemczech np. działalność polskiego alchemika Michała Sędziwoja, którą mogła poznać czytająca Europa także poprzez niemieckie edycje (Wittenlierg 1616, 1623; Köln 1617: Strassburg 1628, 1681: Frankfurt 1667). Cenione w calej Europie pa- 
miętniki polskiego podróżnika hrabiego Maurycego Beniowskiego mamy m.in. w dwóch edycjach niemieckich, a mianowicie Berlin 1790 oraz Hamburg 1791. Problem obecności w naszych zbiorach poloników niemieckich jedynie zasygnalizowano na podstawie kilku egzemplifikacji, zespół ten bowiem jest dość zasobny i wart osobnego opracowania.

$\mathrm{Na} z a k o n ́ c z e n i e ~ c h a r a k t e r y s t y k i$ książi niemieckiej XV-XVIII wieku w Bibliotece Uniwersyteckiej w Warszawie trzeba raz jeszcze przypomnieć, że jej obecność tutaj ma znaczenie zasadnicze, jako że większość pozycji tego rodzaju weszła do naszych zbiorów poprzez polskie historyczne kolekcje w sposób naturalny, zgodny z rytmem rozwoju kultury europejskiej, a nie droga zdobyczy wojennych. Jest to zatem doskonały, obiektywny materiał do badań polsko-niemieckich wpływów i zależności kulturalnych na przestrzeni tych wieków.

\section{Czasopisma}

Biblioteka Uniwersytecka w Warszawie posiada bogaty zespół czasopism, szacowany na ok. 50000 tytułów ujętych w podstawowym katalogu czasopism oraz $\mathrm{w}$ wydzielonych: czasopism rosyjskich, kalendarzy, sprawozdań administracyjnych katalogowanych pod nazwą instytucji, których dotyczą. Ponadto wydzielone są wydawnictwa seryjne i zbiorowe - ok. 20000 tytułów. Specjalnością kolekcji czasopism są rossika, ale przejrzenie katalogów pokazuje, że periodyki niemieckie w obrębie XIX wieku są reprezentowane w podobnej ilości, co rosyjskie. Liczbę germaników określa się na ponad 2000 tytułów, co stanowi ok. 25\% całości wydawnictw ciagłych tego okresu. Czasopisma niemieckie charakteryzują się stabilnością i zgromadzono je w większości bardzo kompletnie. Są to przede wszystkim czasopisma naukowe o profilu humanistycznym i matematyczno-przyrodniczym. Dość dużo, bo ok. 100 tytułów czasopism dotyczy medycyny. W naszych zbiorach znaleźć można sporo almanachów (np. Goethe Jahrbuch Franckfurt 1880-1897), a także dzienników, ale nie są one niestety zawsze kompletne. Skromnie prezentują się czasopisma niemieckie wydawane na terenie obecnej Polski. Są to głównie periodyki z obszaru Śląska, Pomorza i Mazur. Mamy np. 14 tytułów czasopism wydawanych w XIX wieku w Gdańsku. Dość duża grupa to dzienniki urzędowe, jak np. Amts-Blatt der Königlichen Brombergischen Reglerun 1815-1891, Amls-likill der Könglichen Reglertung 
zu Koslin 1821-1898, 1913. Pośród germaników znajdujemy także ok. 70 tytułów kalendarzy z XIX wieku, z czego połowa pochodzi z terenów dzisiejszej Polski. Nie jest to więc zbiór duży, a w dodatku obciążony licznymi brakami w kompletowaniu roczników, bowiem wpływały one do biblioteki sporadycznie. Dla przykładu wymieńmy: Berliner Kalender 1827-1850, Illustrierter Kalender Leipzig 1847-1863, Chemiker Kalender Berlin 1885-1894, Hausfreunde Warszawa 1880-1917 itd.

Katalog sprawozdań administracyjnych zawiera ok. 100 tytułów z XIX wieku, reprezentowany ubogo i w formie niekompletnej. Zazwyczaj są to składy osobowe lub spisy wykładów oraz relacje inauguracji roku akademickiego. Dotyczą one m.in. wyższych uczelni Berlina, Bonn, Gottingen, Monachium, Rostocka i Wiednia. Sprawozdania z terenu Polski dotyczą głównie szkół średnich.

\section{Zbiory muzyczne}

Interesująco wyglądaja zasoby przechowywane w Oddziale Zbiorów Muzycznych. Jest tam ok. 75000 obiektów, z czego 20\% stanowi tzw. „zbiór wrocławski” przechowywany w naszej bibliotece od $1952 \mathrm{r}$. Obejmuje on ok. 15000 jednostek, w tym ok. 10000 książek i druków muzycznych XIX-XX wieku, 1500 starych druków muzycznych XVIXVIII wieku oraz ok. 5000 rękopisów muzycznych XVI-XIX wieku. Germanika w ,zbiorze wrocławskim” stanowią ok. 50-60\% jego całej zawartości. Najcenniejszą część kolekcji stanowią rękopisy i stare druki muzyczne, pochodzące głównie z librarii kościelnych Wrocławia i okolic. Obiekty te zgromadzono w XIX wieku w ówczesnym Instytucie Muzyki Kościelnej (Kirchenmusicalisches Institut) przy Uniwersytecie Wrocławskim. Z natury rzeczy są to więc głównie dzieła o charakterze religijnym, choć wśród starych druków spotykamy także nieliczne publikacje zawierające muzykę świecką oraz 97 cennych traktatów teoretycznych. Trzy z nich pochodzą z XVI wieku, a osiem z XVII wieku. Do najwartościowszych starych druków muzycznych zaliczamy m.in. Dodekachordon Heinricha Glareanusa (Basilea 1547), Johanna Woltza Nova musices organicae tabulatura (Basel 1617) oraz traktaty o charakterze teoretycznym Athanasiusa Kirchera i Michaela Praetoriusa z XVII w. oraz Johanna Matthesona z XVIII wieku. 


\section{Zbiory graficzne}

Zbiory grafiki i rysunku przechowywane w Gabinecie Rycin BUW mimo poważnych strat wojennych, należą do najzasobniejszych w Polsce, a przede wszystkim do najważniejszych pod względem artystycznym. Całość zbiorów liczy ok. $60 \quad 000$ rycin i rysunków luźnych oraz w albumach, w tym grafika obejmuje 52500 prac, rysunki ok. 7500 .

Germanika nie przekraczaja 5-10\% prac w poszczególnych kolekcjach. Sa to obiekty pochodzace $z$ kilku stuleci, począwszy od wieku XVI, a skończywszy na wieku XX. Najwięcej materiału związanego $z$ kulturą niemiecką odnajdujemy w dziale ikonograficznym. Stanowią go głównie portrety i widoki rozmaitych regionów Niemiec i krajów niemieckojęzycznych, ale ryciny te wykonali twórcy z różnych szkół europejskich, nie tylko niemieckich. Warto zasygnalizować prace takich artystów, jak: Albrecht Dürer, Barthel i Hans Sebald Beham, Johann Elias Ridinger, Johann Nepomuk Strixner, Lovis Corinth, Max Liebermann $i$ wielu innych.

W zbiorze rycin i rysunków brak jest $w$ zasadzie kolekcji proweniencyjnie w całości związanej $z$ kręgiem kultury niemieckiej, wyjąwszy zespół 2800 plansz, na których pomieszczono głównie portrety osobistości niemieckich, przekazany do Gabinetu Rycin w latach 1946-1947 z Muzeum Wojska Polskiego w Warszawie. Zespół ten pochodzi z nieznanej nam kolekcji niemieckiej, prawdopodobnie zabrany z jednej z ówczesnych składnic Ministerstwa Kultury i Sztuki na Pomorzu lub na Śląsku. Nie ma on wszakże wielkiej wartości artystycznej, gdyż składa się w dużej mierze $z$ reprodukcji, fotografii, wycinków gazetowych itp.

\section{Zbiory kartograficzne}

Oddział Kartografii nie należy do zbyt dużych jednostek w skali naszego kraju, jednakowoż posiada sporo interesujących obiektów historycznych. Jego zasób to 10192 jednostek inwentarzowych, z czego 805 $(8 \%)$ to germanika wyprodukowane do 1918 roku. Jako germanika traktujemy tu obiekty odnoszące się do terenów niemieckich, jak $\mathrm{i}$ innych krajów na całym globie ziemskim, ale sporządzone przez kartografów niemieckich, bądź w niemieckojezycznych drukarniach. 
Wśród nich znajduje się 35 atlasów z XVI-XVIII wieku, 112 z wieku XIX oraz 27 z początków XX wieku. W grupie atlasów liczącej łącznie 174 obiekty - aż 38 zarejestrowano jako egzemplarze jedyne w Polsce. Niewielki jest zbiór map ściennych, zaledwie 10 pochodzi z XIX wieku, a $4 \mathrm{z}$ początków $X X$ wieku. Map luźnych związanych $z$ tematem niemieckim mamy 461, z czego jedna sięga aż wieku XVI, 4 powstały w wieku XVII, $91 \mathrm{w}$ następnym, $218 \mathrm{w}$ XIX wieku i wreszcie 147 w wieku XX, uwzględnionym tylko do r. 1918. Ponadto w zbiorach znajduje się ok. 160 rozmaitych planów, które powstały począwszy od XVII wieku po 1918 rok.

Najstarszym obiektem w kolekcji kartograficznej jest atlas Ptolemeusza wydany w Strassburgu w 1513 roku. Wyróżniającą się grupą tematyczna, zarówno wśród atlasów, jak i map luźnych, są plany działań wojennych z okresu Wojny Siedmioletniej oraz wojny francusko-pruskiej 1870-1871. Szczególnie wykorzystywane przez czytelników są atlasy nieba, z których 9 wydano w Niemczech, w interesującym nas tutaj okresie. Na uwagę zasługują też polonika niemieckie, a wśród nich Plan von der Stadt Warschau w skali 1:11 500, wykonany przez drezdeńskiego rytownika Josepha Bacha i tamże wytłoczony w 1809 roku. Należy on do najlepszych planów naszej stolicy $\mathrm{z}$ przełomu XVIII/XIX wieku. Równie interesujący obiekt to mapa Administrativ-Karte von Konigreichen Galizien und Lodomerien... in 60 Blattern... sporządzona przez Karla Kummerera i wydana w Wiedniu w latach 1855-1863 w skali 1:115 200 techniką cynkografii. O jej wartości stanowią cechy indywidualne egzemplarza, na którym niebieską barwą zaznaczono granice majątków ziemskich, a czerwoną dopisano nazwiska lub nazwy ich właścicieli."

* Niniejszy szkic powstał w zasadzie na podstawie dostępnej literatury, w niektórych tylko kwestiach sięgano po informacje dostępne w Archiwum BUW. Życzliwość dla tematu okazali także kustosze niektórych oddziałów biblioteki, którzy dostarczyli mi stosownych informacji na temat germaników w swoich kolekcjach. Są to w kolejności alfabetu: mgr Mieczysław Kret, mgr Barbara Litwiniukowa, dr Adam Mrygoń, mgr Barbara Nałęcz, mgr Wanda Rudzińska. Szczególnie wiele zawdzięczam mgr Halinie Mieczkowskiej, od której pochodzą informacje statystyczne na temat druków XV i XVI wieku. Za całość wszakże ponosi odpowiedzialność autorka 


\section{ANEKS}

\section{Katalogi kartkowe Biblioteki Uniwersyteckiej w Warszawie}

Katalogi współczesne

Katalogi główne:

Katalog alfabetyczny druków XIX i XX w., Katalog przedmiotowy druków XIX i XX w.

Katalog centralnych bibliotek wydziałowych,

Katalog polskich i obcych czasopism,

Katalog czasopism rosyjskich,

Katalog kalendarzy,

Katalog sprawozdań administracyjnych (wg miejscowości),

Katalog wydawnictw zbiorowych i seryjnych,

Katalog centralny mikroform bibliotek UW,

Katalog alfabetyczny starych druków (z kartotekami proweniencji oraz drukarzy i nakładców).

Zbiory kartograficzne:

Katalog alfabetyczny haseł geograficznych,

Katalog chronologiczny atlasów,

Katalog tematyczny do historii wojen i wojskowości.

Zbiory graficzne:

Katalog autorów rysunków,

Katalog autorów rycin dawnych,

Katalog autorów rycin nowych,

Katalog rycin wedhug autorów pierwowzoru,

Katalog exlibrisów,

Katalog alfabetyczny dzieł z rycinami i wydań albumowych,

Katalog rzeczowy ogólny zbioru grafiki,

Katalog proweniencji zbioru graficznego.

Zbiory muzyczne:

Katalog alfabetyczny nut,

Katalog alfabetyczny książek,

Katalog starych druków muzycznych,

Katalog systematyczny nut, 
Wśród nich znajduje się 35 atlasów z XVI-XVIII wieku, 112 z wieku XIX oraz 27 z początków XX wieku. W grupie atlasów liczącej łącznie 174 obiekty - aż 38 zarejestrowano jako egzemplarze jedyne w Polsce. Niewielki jest zbiór map ściennych, zaledwie 10 pochodzi z XIX wieku, a 4 z początków XX wieku. Map luźnych zwiazzanych $z$ tematem niemieckim mamy 461, z czego jedna sięga aż wieku XVI, 4 powstały w wieku XVII, 91 w następnym, 218 w XIX wieku i wreszcie 147 w wieku XX, uwzględnionym tylko do r. 1918. Ponadto w zbiorach znajduje się ok. 160 rozmaitych planów, które powstały począwszy od XVII wieku po 1918 rok.

Najstarszym obiektem w kolekcji kartograficznej jest atlas Ptolemeusza wydany w Strassburgu w 1513 roku. Wyróżniająca się grupa tematyczna, zarówno wśród atlasów, jak i map luźnych, są plany działań wojennych z okresu Wojny Siedmioletniej oraz wojny francusko-pruskiej 1870-1871. Szczególnie wykorzystywane przez czytelników są atlasy nieba, z których 9 wydano w Niemczech, w interesującym nas tutaj okresie. Na uwage zasługują też polonika niemieckie, a wśród nich Plan von der Stadt Warschau w skali 1:11 500, wykonany przez drezdeńskiego rytownika Josepha Bacha i tamże wytłoczony w 1809 roku. Należy on do najlepszych planów naszej stolicy z przełomu XVIII/XIX wieku. Równie interesujący obiekt to mapa Administrativ-Karte von Konigreichen Galizien und Lodomerien... in 60 Blattern... sporządzona przez Karla Kummerera i wydana w Wiedniu w latach 1855-1863 w skali 1:115 200 technika cynkografii. O jej wartości stanowią cechy indywidualne egzemplarza, na którym niebieską barwą zaznaczono granice majątków ziemskich, a czerwona dopisano nazwiska lub nazwy ich właścicieli.”

Niniejszy szkic powstał w zasadzie na podstawie dostępnej literatury, w niektórych tylko kwestiach sięgano po informacje dostępne w Archiwum BUW. Życzliwość dla tematu okazali także kustosze niektórych oddziałów biblioteki, którzy dostarczyli mi stosownych informacji na temat germaników w swoich kolekcjach. Sa to w kolejności alfabetu: mgr Mieczysław Kret, mgr Barbara Litwiniukowa, dr Adam Mrygoń, mgr Barbara Nałęcz, mgr Wanda Rudzińska. Szczególnie wiele zawdzięczam mgr Halinie Mieczkowskiej, od której pochodzą informacje statystyczne na temat druków XV i XVI wieku. Za całość wszakże ponosi odpowiedzialność autorka. 


\section{ANEKS}

\section{Katalogi kartkowe Biblioteki Uniwersyteckiej w Warszawie}

Katalogi współczesne

Katalogi główne:

Katalog alfabetyczny druków XIX i XX w., Katalog przedmiotowy druków XIX i XX w.

Katalog centralnych bibliotek wydziałowych,

Katalog polskich i obcych czasopism,

Katalog czasopism rosyjskich,

Katalog kalendarzy,

Katalog sprawozdań administracyjnych (wg miejscowości),

Katalog wydawnictw zbiorowych i seryjnych,

Katalog centralny mikroform bibliotek UW,

Katalog alfabetyczny starych druków (z kartotekami proweniencji oraz drukarzy i nakładców).

Zbiory kartograficzne:

Katalog alfabetyczny hasel geograficznych,

Katalog chronologiczny atlasów,

Katalog tematyczny do historii wojen i wojskowości.

Zbiory graficzne:

Katalog autorów rysunków,

Katalog autorów rycin dawnych,

Katalog autorów rycin nowych,

Katalog rycin według autorów pierwowzoru,

Katalog exlibrisów,

Katalog alfabetyczny dzieł z rycinami i wydań albumowych,

Katalog rzeczowy ogólny zbioru grafiki,

Katalog proweniencji zbioru graficznego.

Zbiory muzyczne:

Katalog alfabetyczny nut,

Katalog alfabetyczny książek,

Katalog starych druków muzycznych,

Katalog systematyczny nut, 
Katalog działowy książek,

Centralny katalog starych druków muzycznych (w bibliotekach polskich).

Katalogi drukowane:

Elżbieta Budzińska: Szkola graficzna Rubensa. Katalog rycin ze zbiorów Gabinetu Rycin BUWW. Warszawa 1975.

Katalog mikrofilmów BUW. Czasopisma. Z. 1-4. Warszawa 1986-1991.

Katalog mikrofilmów BUW. Druki XV-XVIII wieku. Z. 1-2. Warszawa 1986-1989.

Katalog mikrofilmów BIJW. Druki XIX-XX wieku. Z. 1-3. Warszawa 1986-1990.

Katalog mikrofilmów BUW. Zbiory muzyczne. Z. 1. Warszawa 1987.

Teresa Komender (red.): Katalog druków XV i XVI wieku w zbiorach UW. Wstęp: M. Sipayłło. T. 1. Warszawa 1994.

Janina Mendysowa: Katalog druków muzycznych XVI-XVIII wieku. T. 1. Warszawa 1970.

Alina Mrozowska, Tadeusz Majda: Rysunki kostiumów tureckich z kolekcji Stanistawa Augusta w Gabinecie Rycin BUW. Wyd. 2. Warszawa 1991.

Barbara Nałęcz, Ludgarda Pawlaczyk: Katalog polskich czasopism emigracyjnych BUW (do września 1939). Warszawa 1983.

Krystyna Opalińska, Ewa Ciepłowska, Roma Bargielska: Katalog czasopism rosyjskich BUW. T. 1 (A-J). Warszawa 1987.

Wanda Rudzińska: Katalog kolekcji Henryka Grohmana w Gabinecie Rycin BUW. Cz. I. Ryciny i rysunki francuskie XIX-XX wieku. Warszawa 1989.

Stanisława Sawicka, Teresa Sulerzyska: Katalog rysunków z Gabinetu Rycin BUW. Cz. 1-3. Warszawa 1967-1972.

Edward Stańczak (red.): Katalog czasopism polskich BIJW. T. 1-8. Warszawa 1980-1989.

\section{Katalogi historyczne:}

Józef Stanisław Siennicki: Les Elzévir de la Bibliothĕque de l'Université Impériale de Varsovie. Varsovie 1874

Józef Stanisław Siennicki: Récueil des éditions des imprimeurs célèbres de l'Italie, de la linance el de la Belgique conservées dans la Bibli- 
othèque de l'Universite Impériale de Varsovie. Les Alde, les Junte, les Estienne et les Plantin. Varsovie 1880.

Teodor Wierzbowski: Bibliographia Polonica XV ac XVI ss. Vol. I. $\mathrm{Nr}$ 1-800 annorum 1488-1600 opera et editiones, quae in Bibliotheca Universitatis Caesareae Varsoviensis asservantur. Varsavia 1889.

\section{Źródła i opracowania do dziejów BUW}

Archiwalia:

Akta Komisji Rządowej Wyznań Religijnych i Oświecenia Publicznego tyczące się Biblioteki Publicznej w Warszawie. Sygn. ONW 7 A (1821-1841), vol. II-IV, VI-VII. Archiwum BUW.

Archiwum niemieckie dr Wittego, komisarza Staatsbibliothek Warschau 1942-1944. Archiwum BUW.

Archiwum polskiej dyrekcji biblioteki z lat 1942-1944. Archiwum BUW.

Bibliothecoviana Warszawskiej Uniwersyteckiej Biblioteki Leona Bykowskiego (spis źródet i opracowań dotyczących dziejów BUW $\mathrm{z}$ lat 1822-1922). Archiwum BUW.

Inwentarze biblioteczne $z$ lat 1871-1915. Archiwum BUW.

Inwentarz działowy dzieł polskich z r. 1838 i 1846-1849. Archiwum BUW.

Inwentarze rocznych wpływów obiektów bibliotecznych z lat 1835-1836, 1838-1842, 1844-1849, 1850-1870. Archiwum BUW.

Kontrolla dzieł zapotrzebowanych do Czytelni w Bibliotece Głównej 1865-1870. Archiwum BUW.

Spis dzieł wypożyczonych do domu wg alfabetu nazwisk wypożyczających za lata 1863-1865, 1866-1867, 1868-1869, 1870. Archiwum BUW.

Sprawozdanie biblioteki za 1865 rok. W: Otčet po vedomstvu Narodnogo Prosveščenija v Carstve Polskom za 1865 god. 1866. Archiwum BUW.

Sprawozdania biblioteki z lat 1867-1868. Centralne Historyczne Archiwum Państwowe w Petersburgu, fond 733.

Sprawozdania biblioteki z lat 1918-1939. Archiwum BUW.

Opracowania:

Zygmunt Batowski: Zbiór graficzny w' Uniwersylecie Warszawskim. Warszawa 1928 
Józef Bieliński: Królewski Uniwersytet Warszawski. T. 1, s. 742-760: Biblioteka. Warszawa 1907.

Barbara Bieńkowska, Wojciech Kowalski, Hanna Łaskarzewska, Urszula Paszkiewicz, Stanisław Waligórski: Straty bibliotek w czasie II wojny swiatowej w granicach Polski z 1945 roku. Wstęny raport o stanie wiedzy. Warszawa 1994.

Olena Błażejewicz: Biblioteka Liceum Warszawskiego 1806-1831. W: Roczniki Biblioteczne. R. 23 (1979), z. 2, s. 53-92.

Olena Błażejewicz: Dzieje Biblioteki Uniwersyteckiej w Warszawie 18711915. Warszawa 1990.

Helena Kozerska: Straty w zbiorze rękopisów Biblioteki Uniwersyteckiej w Warszawie w czasie I i II wojny światowej. Warszawa 1960.

Helena Kozerska: Warszawska Biblioteka Uniwersytecka w latach 18321871. Biblioteka Rzqdowa - Okręgu Naukowego - Główna. Warszawa 1967.

Wojciech Kriegseisen: Ksiązka i biblioteka w kulturze ewangelików polskich w XVII i XVIII wieku. W: Z Badań Nad Polskimi Księgozbiorami Historycznymi. T. 13. Warszawa 1992, s. 5-40.

Joachim Lelewel: Stan Biblioteki przy Uniwersytecie Warszawskim. W: Bibliograficznych ksiag dwoje. Wilno 1826. T. II, s. 339-419.

Marian Łodyński: Materialy do dziejów państwowej polityki bibliotecznej w Księstwie Warszawskim i Królestwie Polskim (1807-1831). Wrocław 1958.

Krystyna Niklewiczówna: Oddziat Starych Druków BUW 1949-1977. W: Z Badań Nad Polskimi Księgozbiorami Historycznymi. T. 8. Warszawa 1985 , s. 5-56.

Stanisława Sawicka: Cabinet des Estampes de la Bibliotheque de l'Universite de Varsovie. W: Mouseion. Jg. IX (1935), vol. 31/32, nr 3/4, s. 119-125.

Stanisława Sawicka: Gabinet Rycin. Informator. Warszawa 1962.

Stanisława Sawicka: Gabinet Rycin w latach 1939-1949. W: Biuletyn Historii Sztuki. R. 11 (1949), z. 3-4, s. 392-397.

Stanisława Sawicka, Teresa Sulerzyska: Straty w rysunkach z Gabinetu Rycin Biblioteki Uniwersyteckiej 1939-1945. Warszawa 1960.

Maria Sipayłł: Polskie superexlibrisy XVI-XVIII wieku w zbiorach BUW. Warszawa 1988.

Wanda Sokolowska: Dzieje Biblioteki Uniwersyteckiej w Warszawie 1939-1945. Warszawa 1959 
Wanda Stummer: Biblioteka Uniwersytecka w Warszawie. W: Uniwersytet Warszawski 1808-1815-1858. Warszawa 1958, s. 23-56.

Wykaz zawiera tylko opracowania ogólne. Nie uwzględniono opracowań cząstkowych odnoszących się do poszczególnych kolekcji, zespolów lub ich fragmentów.

Ponadto Biblioteka Uniwersytecka w Warszawie dysponuje wieloma drukowanymi katalogami wystaw, na których reprezentowano fragmenty różnych kolekcji, przeważnie zbiorów specjalnych. Ich spis zobacz w: Urszula Paszkiewicz: Bibliografia inwentarzy i katalogów ksiegozbiorów polskich... Cz. 1. Warszawa 1990, s. 227-234.

\section{काष्ट}

